http://dx.doi.org/10.18778/0208-6050.95.13

ANNA SZCZEPAŃSKA

(UNIWERSYTET ŁÓDZKI) ${ }^{*}$

\title{
Rząd Roberta Mugabe wobec polityki Stanów Zjednoczonych Ameryki na południu Afryki (1980-1987)
}

Zimnowojenne zmagania między Stanami Zjednoczonymi i Związkiem Radzieckim występowały również na południu kontynentu afrykańskiego. W wielu krajach Afryki hasła socjalistyczne cieszyły się ogromną popularnością, gdyż mówiły o wolności i równości wszystkich ludzi, a także o sprawiedliwym i równomiernym podziale dóbr. Dla biednej i pogardzanej przez kolonizatorów ludności afrykańskiej perspektywa niepodległości przez wyrównanie ich pozycji wobec białych była kuszącą alternatywą dotychczasowego życia. Dodatkową przyczyną popularności postulatów socjalistycznych były różnorakie deklaracje ze strony ZSRR. Dla wielu afrykańskich przywódców był on wiarygodny, gdyż nie miał za sobą kolonizacyjnej przeszłości. Ponadto udzielał faktycznego, a nie tylko dyplomatycznego, poparcia wielu organizacjom niepodległościowym na terytorium Afryki, pozornie nie domagając się niczego w zamian. Oficjalna, altruistyczna postawa ZSRR stała w sprzeczności z tym, czego Afryka doświadczała dotąd ze strony wszystkich krajów Zachodu. Jednak rosnące wpływy ZSRR w dążących do niepodległości krajach afrykańskich nie podobały się Stanom Zjednoczonym, które również były orędownikami wyzwolenia Afryki spod władzy europejskiej, jednak na innych niż ZSRR zasadach. Obydwu państwom zależało, aby nowo powstałe kraje nie dostały się pod wpływy konkurenta, gdyż to destabilizowałoby ich pozycję. Zdawano sobie także sprawę z surowcowych możliwości krajów afrykańskich. Ponadto uzyskanie wpływów w ostatnim „nieokreślonym” ideologicznie rejonie globu dodawało prestiżu i potwierdzało słuszność czy to socjalizmu, czy kapitalizmu jako drogi rozwoju.

Jednym z ostatnich państw afrykańskich, które uzyskało niepodległość, była Republika Zimbabwe. Droga do wolności była długa i wyboista, stanowiła też klasyczny przykład starcia między mocarstwami. Zimbabwe - przed uzyskaniem niezależności Rodezja Południowa - znajdowało się pod wpływami Wielkiej

* Wydział Filozoficzno-Historyczny, Instytut Historii, Katedra Historii Powszechnej Najnowszej. 
Brytanii. Wygrane wybory dnia 14 grudnia 1962 r. przez Front Rodezyjski pod przywództwem Iana Smitha ${ }^{1}$ nieco odwróciły układ sił w kraju. Do władzy doszli politycy wrogo nastawieni do Wielkiej Brytanii, wywodzący się ze środowiska białych farmerów i plantatorów. Smith dążył do uwolnienia się spod wpływów brytyjskich z jednoczesnym monopolem na władzę tylko białej, mniejszościowej części społeczeństwa. Swoje rządy oparł na zasadach doktryny apartheidu, obowiązującej w sąsiedniej Republice Południowej Afryki. Afrykańczykom w Rodezji żyło się coraz gorzej. Ich prawa zaczęto znacznie ograniczać. Niezadowolenie społeczne rosło ze świadomością polityczną. Wiele państw Afryki uzyskało niepodległość, kolejne walczyły o wolność. Ruchy narodowowyzwoleńcze zaczęły powstawać także w Rodezji. Pierwsza organizacja: ANC (ang. African National Congress) powstała w 1957 r., lecz szybko została zdelegalizowana. Kolejne, mające mniejsze lub większe znaczenie, ostatecznie skupiły się wokół dwóch największych ugrupowań: Zimbabwe African National Union (ZANU) pod przywództwem Roberta Mugabe oraz Zimbabwe African People's Union (ZAPU), któremu przewodniczył Joshua Nkomo². Do zbrojnych starć na terytorium Rodezji między stroną rządową a oddziałami wyzwoleńczej partyzantki dochodziło od początku lat sześćdziesiątych ${ }^{3}$, a od 1965 r., kiedy Ian Smith ogłosił tzw. jednostronną deklarację niepodległości ${ }^{4}$, sporadyczne incydenty przerodziły się $\mathrm{w}$ regularne walki, a następnie wojnę domową trwającą niemal 15 lat.

Zarówno USA, jak i ZSRR wykorzystały kryzys rodezyjski do próby rozszerzenia wpływów na tym terytorium. Podczas gdy Moskwa udzieliła poparcia organizacji ZAPU Joshui Nkomo, Waszyngton upatrzył swego kandydata na przywódcę przyszłego, wolnego państwa w osobie Roberta Mugabe i jego partii ZANU. Poparcie dla ZANU jednocześnie oznaczało zbliżenie z państwami, które dyplomatycznie i militarnie wspierały to ugrupowanie, czyli Tanzanią, Zambią, Mozambikiem i Botswaną.

Warto zaznaczyć, że w owym czasie w południowym rejonie kontynentu USA i ZSRR miały już swoich „faworytów”. Do istotnego problemu regionu

\footnotetext{
${ }^{1}$ M.J. M a l i n o w s k i, Zimbabwe u wrót niepodległości, Warszawa 1980, s. 96.

2 Joshua Nkomo (1917-1999) - przywódca nacjonalistyczny, później współpracownik Mugabe, następnie jego przeciwnik; przywódca ZAPU, minister spraw wewnętrznych Zimbabwe w latach 1980-1981, w 1982 r. usunięty z rządu; premier w latach 1989-1998; vide: M. O r 1 e a n s, Encyclopedia of World Biography, vol. XI, Detroit 1998, s. 406.

${ }^{3}$ M. M e r e d i th, Mugabe. Power, Plunder and the Struggle for Zimbabwe, New York 2007, s. 30 .

${ }^{4}$ Jednostronna deklaracja niepodległości (ang. Unilateral Declaration of Independence) została ogłoszona przez rząd Iana Smitha 11 XI 1965 r. jako wyraz niezależności i niepodległości państwa oraz wyjście spod jurysdykcji Wielkiej Brytanii. „Niepodległość” Rodezji nie została uznana przez żadne państwo oprócz RPA; vide: M.J. M a 1 i n o w s k i, Zimbabwe..., s. 112-115.
} 
należał stosunek do RPA - państwa krytykowanego na świecie z powodu wprowadzenia systemu segregacji rasowej (ang. apartheid) oraz okupacji terytorium Namibii, która oficjalnie podlegała pod zarząd powierniczy ONZ. Jednak USA nie zgadzały się na bojkot RPA, mając z nią bardzo dobre kontakty. Inaczej było w przypadku ZSRR, który oficjalnie nie utrzymywał z RPA stosunków dyplomatycznych.

Kolejnym problemem była kwestia niepodległości Namibii. Podczas gdy Związek Radziecki opowiadał się za uznaniem praw Namibii do niezależnej państwowości, Stany Zjednoczone pragnęły, aby pozostała ona zależna od RPA. Amerykanie obawiali się, że w wolnym państwie władzę przejmie przyjaźnie nastawione do ZSRR ugrupowania SWAPO (ang. South-West African People's Organisation $)^{5}$. Nie chcieli dopuścić, aby potencjalnie prosowiecko ukierunkowana Namibia zacieśniła kontakty z Angolą, wybitnie sympatyzującą z ZSRR.

Mozambik, podobnie jak Angola, znajdował się pod silnymi wpływami Moskwy. Natomiast Botswana i Zambia bardzo krytycznie przyglądały się polityce Pretorii, przez co dość nieufnie podchodziły do Waszyngtonu.

$\mathrm{U}$ progu lat osiemdziesiątych południe kontynentu afrykańskiego stanowiło zatem niestabilną mozaikę powiązań. Dla mocarstw siła wpływów w tym regionie miała strategiczne znaczenie, nie tylko w kontekście Afryki, lecz także glo$\mathrm{bu}^{6}$. Zimbabwe zaś nie zamierzało stać się jedynie podporządkowanym jednemu $\mathrm{z}$ nich pionkiem.

$\mathrm{Z}$ wojny domowej w Zimbabwe, po wieloletnich walkach i wielu dyplomatycznych bataliach, o których szczegółach można przeczytać w szeregu publikacji ${ }^{7}$, wyszedł zwycięsko Robert Mugabe. Pierwsze wolne wybory w niepodległym państwie Zimbabwe przeprowadzono w lutym 1980 r. Po ogłoszeniu wyników, kiedy okazało się, że partia ZANU uzyskała większość głosów i 57 na 100 miejsc

${ }^{5}$ South-West Africa People's Organisation (SWAPO) - partia utworzona w 1960 r. przez Sama Nujoma, jednego z najbardziej aktywnych namibijskich działaczy niepodległościowych. Po uzyskaniu niepodległości przez Namibię w 1990 r. Nujoma został pierwszym prezydentem kraju. Więcej na ten temat m.in.: M.J. M a li n o w s k i, Namibia u wrót niepodległości, Warszawa 1981; C.J. T s o k o d a y i, Namibia's Independence Struggle, Bloomington 2011; M. W a 11 a c e, A History of Namibia, Oxford 2011.

${ }^{6}$ A. Y o u n g, The United States and Africa. Victory for diplomacy, „Foreign Affairs”, 2 XII 1980, s. 649.

${ }^{7}$ Więcej o przebiegu walk oraz międzynarodowych konsekwencjach wojny o niepodległość Zimbabwe m.in.: T. D o b o s i e w i c z, T. $Ł$ ę t o c h a, M.J. M a 1 i n o w s k i, Rola armii w Afryce, Warszawa 1970; J. Kiwerska, Rozpad imperium brytyjskiego $w$ Afryce, Warszawa 1989; M. L e ś n i e w s k i, Zimbabwe czy Rodezja 1965-1981, [w:] Przywództwo i przywódcy we wspótczesnej Afryce, red. A. Żukowski, t. VII, Olsztyn 2008; M.J. M a l i n o w s k i, Kryzys rodezyjski, Warszawa 1975; i d e m, Zimbabwe...; D. M a r t i n, J. P h y 11 i s, The Struggle for Zimbabwe. The Chimurenga War, London 1981; M. M e r e d i th, Mugabe... 
w parlamencie ${ }^{8}$, w depeszy do swego ambasadora w Londynie Departament Stanu USA pisał, że ,głosowanie zakończyło się wynikiem najlepszym z możliwych",

Młode państwo, wyniszczone kilkunastoletnią wojną domową, wymagało odbudowy. Mugabe liczył na pomoc Zachodu. Wielka Brytania obiecała przekazać ok. 115 mln dolarów ${ }^{10}$, pomoc amerykańska miała wynieść 70-75 mln dolarów ${ }^{11}$. Już w czerwcu 1980 r. Amerykanie wysłali do Salisbury przedstawicieli Departamentu Stanu oraz biznesmenów, którzy mieli się zorientować w możliwościach gospodarczych kraju. Delegacja wyraziła nadzieję rozwoju współpracy, co bardzo dobrze rokowało dalszym relacjom ze Stanami Zjednoczonymi ${ }^{12}$. Mugabe z nadzieją oczekiwał na hojną pomoc.

Wkrótce po wyjeździe Amerykanów premier Mugabe osobiście udał się do Waszyngtonu. Głównym celem wizyty było uzyskanie pomocy finansowej. Zdecydowano wówczas o zorganizowaniu międzynarodowej konferencji na rzecz pomocy Zimbabwe. W marcu 1981 r. na sympozjum do Harare przybyło 250 delegatów z 40 krajów. Mugabe i jego ministrowie liczyli na pomoc rzędu 1,2 mld dolarów przeznaczonych na odbudowę kraju ze zniszczeń wojennych ${ }^{13}$. Minister gospodarki Bernard Chidzero zachęcał do inwestycji, zapewniając o ułatwionym dostępie kapitału zagranicznego do lokowania w Zimbabwe. Ostatecznie władze Republiki uzyskały ponad 1,2 mld dolarów, $\mathrm{z}$ czego pierwsza połowa została przekazana jako dary, a druga jako niskoprocentowe pożyczki ${ }^{14}$. Było to wydarzenie bez precedensu, pokazujące wyjątkowy status, jakim cieszyło się Zimbabwe.

${ }^{8}$ Oprócz partii Mugabe w parlamencie zasiadło 20 przedstawicielu partii ZAPU, troje członków ugrupowania skupionego wokół Abla Muzorewy. Pozostałe 20 miejsc było „ustawowo” przeznaczonych dla białych mieszkańców kraju; J. D a vidow, Dealing with international crisses: lessons from Zimbabwe, Muscantine 1983, s. 9-12. Liczbę 20 miejsc w parlamencie dla białych gwarantowało porozumienie z Lancaster House w Londynie, podpisane 21 XII 1979 r. przez przedstawicieli Roberta Mugabe, Joshuę Nkomo, Abla Muzorewa, Iana Smitha oraz Brytyjczyków czuwających nad przebiegiem transformacji Rodezji w niepodległe państwo, vide: 13 II 1979, From Embassy London to Secretary of State, Washington District, Subject: London Conference - Meeting with Nkomo, http://foia.state.gov/searchapp/DOCUMENTS/1FY2013/F201101527/DOC_0C 17669735/C17669735.pdf (dostęp: 25 I 2016).

${ }^{9} 19$ II 1980, From Secretary of State Washington District to Embassy London; Subject: Issues and mood for Carrington meeting, http://foia.state.gov/searchapp/DOCUMENTS/1-FY2013/F20 1101527/DOC_0C17669751/C17669751.pdf(dostęp: 25 I 2016).

${ }^{10}$ X. S m i l e y, Zimbabwe, South Africa and the rise of Robert Mugabe, „Foreign Affairs”, 1 VI 1980, s. 1082.

11 A. Y o u ng, op. cit., s. 650. Ostatecznie amerykańska pomoc finansowa dla Zimbabwe w latach 1980-1983 wyniosła 223 mln dolarów, vide: Biuletyn Specjalny Polskiej Agencji Prasowej [dalej: BS PAP], 15 IX 1983, dział informacji [dalej: dz. inf.], s. 25.

${ }^{12}$ BS PAP, 6 VI 1980, dz. inf., s. 22.

${ }^{13}$ W konferencji nie uczestniczył ZSRR; vide: BS PAP, 23 III 1981, dz. inf., s. 30.

${ }^{14}$ BS PAP, 31 III 1981, dział publicystyki [dalej: dz. publ.], s. 30. 
Pierwsze rysy w relacjach między Harare ${ }^{15}$ i Waszyngtonem pojawiły się już w połowie 1982 r. ${ }^{16}$ Powodem była różnica zdań w kwestii niepodległości Namibii $^{17}$. Ta sprawa zdeterminowała tematykę rozmów między państwami na kolejne lata. Zimbabwe szczerze pragnęło wyzwolenia Namibii spod południowoafrykańskiej okupacji, a w konsekwencji osłabienia wpływów RPA w regionie. Stany Zjednoczone natomiast konsekwentnie opowiadały się po stronie RPA, m.in. dlatego że nie chciały dopuścić do przechwycenia władzy w Namibii przez ugrupowanie SWAPO, gdyż to wzmocniłoby pozycję ZSRR.

We wrześniu 1983 r. Robert Mugabe ponownie udał się do Waszyngtonu ${ }^{18}$. Najważniejszym punktem tej wizyty było omówienie obecności wojsk kubańskich w Angoli ${ }^{19}$. Premier uważał, że stacjonowanie Kubańczyków nie stanowi przeszkody we wsparciu Namibii w jej dążeniach niepodległościowych, z czym nie zgadzał się Ronald Reagan, będąc zdania, że rozmowy o niezależności Namibii nie rozpoczną się, dopóki wojska Fidela Castro pozostają w Afryce ${ }^{20}$. Wydarzenia w Namibii i Angoli zaprzątały myśli dyplomatów wcześniej, stając się powodem spięć na linii Harare-Waszyngton. Mugabe z uporem powtarzał, że nie widzi związku między obecnością Kuby na kontynencie a przyzwoleniem na niepodległość Namibii. Podczas spotkania z amerykańskimi dyplomatami w Harare we wrześniu 1982 r. powiedział: „nie rozumiem, dlaczego Namibijczycy mają być karani brakiem niepodległości tylko dlatego, że ich sąsiad zaprosił do siebie Kubę",21.

${ }^{15}$ Stolica Salisbury zmieniła nazwę na Harare 18 IV 1982 r., w drugą rocznicę odzyskania niepodległości, Harare - formerly known as Salisbury, the Capital of Zimbabwe: http://www.fareaway. com/2009/02/harare-formerly-known-as-salisbury-the-capital-of-zimbabwe/ all/1/ (dostęp: 25 I 2016).

${ }^{16}$ J.S. Whitaker, Africa Beset, „Foreign Affairs”, 1 I 1984, s. 767.

${ }^{17}$ Namibia znajdowała się pod jurysdykcją RPA od 1945 r. Sprawa uzyskania niepodległości przez ostatnie afrykańskie państwo nabierała coraz większego znaczenia z roku na rok. Była to jedna $z$ najczęściej dyskutowanych spraw na forum ONZ.

${ }^{18}$ BS PAP, 15 IX 1983, dz. inf., s. 26; BS PAP, 20 IX 1983, dz. inf., s. 26.

${ }^{19}$ Pierwsze oddziały kubańskie przybyły do Angoli na początku 1975 r. O kubańską pomoc starał się prezydent Agostinho Neto, którego władza była zagrożona przez opozycyjną organizację UNITA, wspieraną przez RPA i USA. Więcej o sytuacji w Angoli m.in.: E. C i m e n t, Angola and Mozambique: Postcolonial Wars in Southern Africa, New York 1997; E. Ge o r g e, The Cuban Intervention in Angola, London-New York 2005; R.K. H e r r m a n n, Regional Conflicts as Turning Points. The Soviets and American Withdrawal from Afghanistan, Angola and Nicaragua, [w:] Interpretation, Causation, and the Study of International Relation, eds R.K. Herrmann, R.N. Lebow, New York 2004; L. K u k k u k, Letters to Gabriella. Angola's Last War for Peace: What the UN did and why, Saratosa 2005; J.F. W a $1 \mathrm{ke} \mathrm{r}$, A Certain Curve of Horn: The Hundred-Year Quest for the Giant Sable Antelope of Angola, New York 2002.

${ }^{20} 13$ IX 1983, Notatka służbowa, Departament Stanu USA, http://foia.state.gov/searchapp /DOCUMENTS/9-30FY2013/F201100929/DOC_0C05182947/C05182947.pdf (dostęp: 25 I 2016).

${ }^{21} 1$ IX 1982, From Embassy Harare to Secretary of State Washington District, Subject: William Cassey Meeting with Prime Minister Mugabe, Namibia, Zimbabwe - South Africa Relation, Internal 
Trudno powiedzieć, czy Mugabe rzeczywiście liczył na zmianę stanowiska Waszyngtonu w sprawie Namibii. Musiał wiedzieć, że jednym z pierwszych haseł wysuniętych przez administrację Reagana po objęciu przez niego prezydentury w 1981 r. było uzależnienie niepodległości Namibii od opuszczenia przez oddziały kubańskie Angoli ${ }^{22}$, co zostało zawarte w formule tzw. powiązania (ang. linkage $)^{23}$. Nawet jeżeli Mugabe wiedział, że Reagan nie zmieni zdania i nie zaostrzy kursu wobec RPA okupującej Namibię, nie zamierzał się wycofać ze swego stanowiska, przedkładając dobro bliskiego mu państwa nad tak ważny, międzynarodowy sojusz.

Mimo odmiennych stanowisk relacje między państwami nadal układały się poprawnie, co było raczej zasługą Waszyngtonu. Dla USA młode, afrykańskie państwo było istotnym elementem polityki. Powstanie i rozwój Zimbabwe w kręgach dyplomacji amerykańskiej nazwano „eksperymentem” ${ }^{24}$. Według założeń miał być to kraj wzorcowy, dowód na koegzystencję ras i kultur, stabilizator sytuacji w regionie i przykład dla demokratycznych zmian w RPA. Był to powód znacznych starań amerykańskiej administracji w podtrzymaniu z Zimbabwe dobrych kontaktów, nawet mimo pewnej „ekstrawagancji” premiera Mugabe.

Stany Zjednoczone, utrzymując dobre stosunki z Pretorią, przymykały oko na niesprawiedliwy system segregacji rasowej, gdyż potrzebowały RPA w odpieraniu wpływów radzieckich na Czarnym Lądzie. Jednocześnie wiele wskazuje na to, że aż do połowy lat osiemdziesiątych USA chroniło Zimbabwe przed bezpośrednimi atakami RPA i starało się neutralizować zarzuty Pretorii dotyczące pomocy Harare dla partyzantki ANC-SA ${ }^{25}$. Na tym jednak kończyła się wspólnota „interesów” obydwu krajów, z czego Mugabe musiał zdawać sobie sprawę ${ }^{26}$.

Situation, http://foia.state.gov/searchapp/DOCUMENTS/5-FY2014/F201229009/DOC_0C05256484/ C05256484.pdf (dostęp: 25 I 2016), thum. własne.

22 J. d e S t. J o r r e, Africa. Crisis of Confidence, „Foreign Affairs”, 1 III 1983; A. G ą s o w s k i, RPA, Warszawa 2006, s. 190.

${ }^{23}$ J. Hashimoto, Cold War Chat: Chester Crocker, Former U.S. Assistant Secretary of State for African Affairs, https://web.archive.org/web/20060923171400/http://www.cnn.com/SPECIALS/ cold.war/guides/debate/chats/crocker/ (dostęp: 25 I 2016).

${ }^{24} 29$ X 1982, From Embassy Salisbury to Secretary of State Washington District; Subject: Whiter Zimbabwe, http://foia.state.gov/searchapp/DOCUMENTS/5-FY2014/F-2012-29009/DOC_ 0C05256526/ C05256526.pdf (dostęp: 25 I 2016); M. M e r e d i t h, Mugabe..., s. 47.

${ }^{25}$ ANC-SA (ang. African National Congress - South Africa) była organizacją niepodległościową założoną w 1912 r. jako SANNC (ang. The South African Native National Congress), przekształconą w 1923 r. w ANC. Do najsłynniejszych działaczy należeli m.in. Nelson Mandela i Thabo Mbeki; A brief history of the African National Congress: http://www.anc.org.za/show.php?id=206 (dostęp: 25 I 2016); 1 IX 1982, From Embassy Harare to Secretary of State Washington District, Subject: William Cassey Meeting with Prime Minister Mugabe, Namibia, Zimbabwe - South Africa Relation, Internal Situation, http://foia.state.gov/searchapp/DOCUMENTS/5-FY2014/F201229009/ DOC_0C05256484/C05256484.pdf(dostęp: 25 I 2016).

${ }^{26}$ J.S. W h i t a k e r, op. cit., s. 767. 
Zimbabwe nie popierało żadnego z układów, jakie USA zawierało - oficjalnie lub nieoficjalnie - w państwach południa Afryki. W Angoli powszechnie uznana władza partii MPLA (port. Movimento Popular de Libertação de Angola) nie została przyjęta przez Amerykanów, którzy zaczęli finansować opozycyjną partię UNITA (port. União Nacional para a Independência Total de Angola) pod przywództwem Jonasa Savimbi, podsycając wojnę domową w kraju. Podobnie rzecz miała się w Mozambiku, gdzie prosowiecki prezydent Samora Machel należący do partii FRELIMO (port. Frente de Libertação de Moçambique) był niewygodny dla Waszyngtonu, który postanowił udzielić pomocy jego oponentowi André Matsangaissowi i partii RENAMO (port. Resistência Nacional Moçambicana) ${ }^{27}$.

Znaczne zaostrzenie kursu na linii stosunków amerykańsko-zimbabweńskich nastąpiło podczas konferencji prasowej w siedzibie ONZ. Wówczas Mugabe skrytykował postawę USA wobec RPA oraz obarczył winą Amerykanów za blokowanie działań na rzecz niepodległości Namibii. Waszyngton stwierdził, że wycofanie wojsk kubańskich z Angoli, będące pierwszym krokiem w stronę rozmów o niepodległości Namibii, jest stanowiskiem Republiki Południowej Afryki. Mugabe odparł, że to opinia USA, którą RPA jedynie przyjęło ${ }^{28}$. Mimo ostrzejszej wymiany zdań Stany Zjednoczone nie zrezygnowały z pomocy finansowej dla Zimbabwe, które miało wynieść kolejne 75 mln dolarów ${ }^{29}$.

Dnia 31 października 1983 r. w Zimbabwe doszło do aresztowania byłego premiera i działacza ANC, biskupa Abla Muzorewy. Jako powód podano jego działalność wywrotową w powiązaniu z RPA. Muzorewa był ponadto krytykowany za swoje niedawne wizyty w Egipcie i Izraelu, z którymi Zimbabwe nie utrzymywało kontaktów. Aresztowanie Muzorewy spotkało się z niezadowoleniem rządu USA ${ }^{30}$. Państwowa gazeta „The Harald” amerykańskie protesty skomentowała w ironiczny sposób, dając do zrozumienia, że wiedzą, w jaki sposób Amerykanie pragnęliby ukształtować władzę w regionie: „Łatwo wyciągnąć wniosek, że Amerykanie chcą być żandarmem świata, ustanawiając rządy według swego życzenia [...] i narzucając osoby im sprzyjające"31.

Stosunek rządu Roberta Mugabe do polityki Stanów Zjednoczonych ulegał systematycznemu oziębieniu, co wiązało się z zacieśnianiem kontaktów ze

${ }^{27} \mathrm{~W}$ połowie lat osiemdziesiątych USA zaprzestało wspierania RENAMO, gdy na jaw wyszły brutalne metody walki organizacji (m.in. porwania dzieci, zmuszanie do prostytucji). Więcej na ten temat: V. Igre ja, The Monkey's Sworn Oath. Cultures of Engagement for Reconciliation and Healing in the Aftermath of the Civil War in Mozambique, Leiden 2007.

${ }^{28}$ BS PAP, 23 IX 1983, dz. inf., s. 24.

29 „Washington Post”, 22 X 1983. Według innego źródła pomoc USA dla Zimbabwe została zmniejszona z $75 \mathrm{mln}$ do $60 \mathrm{mln}$ dolarów, a na rok 1984 zaplanowano ją w wysokości $40 \mathrm{mln}$, vide: J.S. W h i t a k e r, op. cit., s. 768.

${ }^{30}$ BS PAP, 7 XI 1983, dz. inf., s. 29.

31 „The Harald”, 5 XI 1983, za: BS PAP, 7 XI 1983, dz. inf., s. 29. 
Związkiem Radzieckim ${ }^{32}$ oraz coraz bardziej agresywnymi działaniami Republiki Południowej Afryki. Od drugiej połowy 1985 r. nastąpił wzrost napięcia na pograniczu Zimbabwe i RPA. Na terytorium Zimbabwe, przy granicy z RPA, swoje bazy miała południowoafrykańska organizacja niepodległościowa ANCSA. Stąd także dokonywała wypadów zbrojnych na obszar Republiki Południowej Afryki. Pretoria nie zamierzała tolerować ataków „rebeliantów”, grożąc wtargnięciem swoich wojsk na teren Zimbabwe ${ }^{33}$. Do bezpośredniego ataku doszło 19 maja 1986 r., kiedy grupa komandosów południowoafrykańskich została zrzucona z samolotu nad Harare i ostrzelała domy, w których mieli się ukrywać przywódcy ANC. Atak został potępiony przez Stany Zjednoczone, Wielką Brytanię oraz państwa Commonwealthu. Nie wystosowano jednak żadnych sankcji wobec agresora, choć tego spodziewało się Zimbabwe. Dla rządu Roberta Mugabe był to kolejny powód, aby ograniczyć zaufanie do Waszyngtonu.

Do kontrowersyjnych wydarzeń doszło podczas uroczystości z okazji Święta Niepodległości Stanów Zjednoczonych, które odbywały się w siedzibie ambasady USA w Harare. Podczas bankietu zimbabweński minister sportu David Karimanzira wygłosił przemówienie, w którym w ostrych słowach skrytykował politykę Waszyngtonu. Zarzucił Stanom Zjednoczonym hipokryzję, potępiając stosowanie sankcji wobec Polski, Libii czy Nikaragui i jednoczesne ignorowanie terroryzmu RPA. Słowa te wywołały burzę - salę opuścił m.in. obecny na przyjęciu były prezydent USA Jimmy Carter, a także dyplomaci Holandii, RFN i Wielkiej Brytanii. Departament Stanu USA domagał się wyjaśnień oraz przeprosin. Całe zajście uznano za nadużycie przyjaźni i gościnności ${ }^{34}$. Konsekwencją incydentu było anulowanie pomocy finansowej, jaką Stany Zjednoczone miały przeznaczyć dla Zimbabwe ${ }^{35}$.

Wydarzenia $\mathrm{z}$ ambasady amerykańskiej położyły się cieniem na wzajemnych relacjach. Stany Zjednoczone przestały zabiegać o względy Zimbabwe, jak robiły to dotychczas. Przeorientowanie polityki widać w dyrektywie Ronalda Reagana, opublikowanej przez CIA. Reagan zauważył, że USA powinny zacieśnić współpracę $\mathrm{z}$ innymi krajami południa Afryki, zdolnymi do większego kompromisu, takimi jak: Botswana, Malawi, Zambia i Suazi. Stwierdził także, że dotychczasowe działania Zimbabwe były zbyt sprzeczne, więc nie mogły być uznane za podstawę do prowadzenia dalszych kontaktów. Reagan pytał retorycznie: ,jaki interes możemy mieć my [Amerykanie] w politycznym »survivalu« Mugabe?"36.

\footnotetext{
${ }^{32}$ BS PAP, 9 XII 1985, dz. inf., s. 20.

${ }^{33}$ BS PAP, 23 XI 1985, dz. inf., s. 25, BS PAP, 16 XII 1985, dz. inf., s. 27.

${ }^{34}$ BS PAP, 6 VII 1986, dz. inf., s. 21.

${ }^{35}$ BS PAP, 4 IX 1986, dz. inf., s. 23.

${ }^{36}$ National Security Study, Directive No. 9-87, 18 V 1987: Ronald Reagan, Southern Africa. U.S Policy Toward the Front Line State, www.research.archives.govsearchexpression=zimbabwe\& pg_src=brief\&data-source=online (dostęp: 25 I 2016).
} 
Jednak działania rządu w Harare nie wydają się nieprzemyślaną, szaleńczą polityką, jak chciałby to widzieć Reagan. Dla Roberta Mugabe celem polityki zagranicznej było umacnianie pozycji Zimbabwe na kontynencie afrykańskim. Nie chciał dopuścić do uzależnienia państwa wobec jednego z mocarstw.

U progu lat osiemdziesiątych rząd Roberta Mugabe zwrócił się w stronę Stanów Zjednoczonych, co było następstwem trzeźwego osądu gospodarczej sytuacji kraju. Mugabe wiedział, że takich sum, jakie może ofiarować Zachód, nie będzie $\mathrm{w}$ stanie zapewnić ZSRR ${ }^{37}$. Zdawał sobie sprawę z zacofania własnego kraju, braku miejsc pracy i perspektyw rozwoju dla milionów obywateli. Rozwiązanie widział w zachodnim modelu gospodarczym. Mówił: „bez względu na nasze poglądy musimy budować na tej podstawie [tj. kapitalizmie] naszą przyszłość. Przekształceń dokonywać można tylko stopniowo"38.

Wraz z umocnieniem swojej pozycji w kraju oraz rozszerzeniem kontaktów na całym świecie Mugabe przestał potrzebować USA w takim stopniu, jak u progu swoich rządów. Prawdopodobnie w sferze wpływów zachodnich nie czuł się komfortowo. Pamiętał o konferencji w Londynie w grudniu 1979 r., która została zwołana z inicjatywy Wielkiej Brytanii, kiedy podpisano porozumienie o zawieszeniu broni między stronami w wojnie domowej. Dla Roberta Mugabe nie był to sukces, lecz narzucony pokój, który nie dawał prerogatyw do sprawowania niepodzielnej władzy. Był przekonany, że jego oddziały zbrojne były w stanie wygrać wojnę i wyjść z niej jako zwycięzcy. Zmuszony do podpisania porozumienia, musiał podzielić się władzą, zarówno z partią Nkomo, jak i z białymi obywatelami $^{39}$. Jednoczesny brak entuzjazmu dla Związku Radzieckiego spowodował, że najlepszym rozwiązaniem było utrzymanie dobrych kontaktów ze Stanami Zjednoczonymi, jednak Mugabe nie zamierzał poddać swego kraju pod dyktat Waszyngtonu. Priorytetem było dla niego całkowite wyzwolenie Afryki spod władzy białej mniejszości oraz uspokojenie sytuacji w regionie. Mugabe zdecydowanie przedkładał dobro bliskich mu krajów afrykańskich nad sojusz z USA. Uważał, że jego państwo może pozostać niezależne. W polityce zagranicznej wybrał drogę niezaangażowania jako najwłaściwszą dla pozycji Zimbabwe na arenie międzynarodowej.

${ }^{37}$ Tylko w pierwszym roku rządów Mugabe Zimbabwe otrzymało od państw zachodnich pomoc finansową w kwocie około 1,5 mld dolarów, vide: M. M e re dit h, Historia współczesnej Afryki. Pót wieku niepodległości, Warszawa 2011, s. 550.

${ }^{38}$ Ibidem, s. 549.

${ }^{39}$ Ibidem, s. 294. 


\section{Robert Mugabe Government towards the policy of the United States of America in Southern Africa (1980-1987)}

The purpose of the article is presentation of the Republic of Zimbabwe attitude towards American policy in Southern Africa and some elements of relations between countries.

An initial relations between Zimbabwe and US was very correct but after first two years (after Zimbabwe's independence in 1980) it became colder. The US hoped to include Zimbabwe in their sphere of influence. Washington wanted wider influences in Southern Africa thus they engaged diplomatic in civil war in Angola and did not agree with independence of Namibia. They kept relations with RSA also.

Zimbabwe, as a regional leader, did not agree with the American policy. American activities in Southern Africa were a reason of extended conflicts in Angola and Namibia. Different opinions the Zimbabwe and US governments were an end of relations between countries.

The Harare policy was not a direct reason of solution conflicts in Southern Africa but the Robert Mugabe actions strengthen the position of Zimbabwe in Africa and in the world. 